UDC 636.52/.58:575.113/.118

(C) 2016

\title{
L. Shulika
}

Institute of Animal Science of NAAS

*Scientific supervisor - Kulibaba R., head of laboratory of disease prevention and molecular diagnostics of State Poultry Research Station of NAAS, PhD, senior researcher

\section{GENETIC STRUCTURE OF TWO LINES OF HENS OF THE COMBINED DIRECTION OF PRODUCTIVITY ON LOCUSES MSTN AND TLR4}

The purpose. To study genetic structure of populations of hens of line G2 (Plimutrok Belyi) and line 38 (Rodisland Krasnyi) on locuses MSTN and TLR4. Methods. Polymerase chain reaction - polymorphism of length of destruction fragments. Results. Frequencies of alleles $A$ and $G$ on locus MSTN have made 0,33 and 0,67 in line $G 2 ; 0$ and 1 in line 38; of alleles $A$ and $B$ on locus TLR4 - 0,3 and 0,7 in line $G 2 ; 0,66$ and 0,34 in line 38 .

Conclusions. Gene TLR4 is polymorphic in both lines, and MSTN - only in line G2. On gene MSTN the deflexion from genetic equilibrium in line $\mathrm{G} 2$ is fixed. The probed populations are essentially differ on genetic structure on both locuses.

Key words: genetic structure, hens, restriction analysis, gene of myostatinum (MSTN), gene of tall-like receptor 4 (TLR4).

Lately, increasing attention is given to studying of functional polymorphism of candidate genes and researching of genetic-populational structure of lines and breeds of poultry on DNA-markers with the aim of marker-assisted selection [1, 3, 5, 9]. Such candidate genes include myostatin gene $(M S T N)$, which is negative regulator of the growth of skeletal muscles, and toll-like receptor gene 4 (TLR4), that takes part in the immune response activation $[4,6-8,10]$. Mutations that have been selected for studying - transition G2109A (Hpall-polymorphism) in MSTN first exon, which associated with body weight, breast muscle weight and abdominal fat weight, and transversion G3954C (Sau96I -polymorphism) in TLR4 second exon, which associated with bacterial load on spleen in some chicken breeds $[4,7,10]$. For Ukrainian population of dual-purpose chicken (line G2 of White Plymouth Rock - meat-and-egg and line 38 of Rhode Island Red - egg-and- 
meat productivity types of breeds) data about the genetic structure on mentioned mutations are not available, and this determines the relevance and the newness of this investigation.

The purpose. To study the genetic structure of population of chicken of line G2 of White Plymouth Rock breed and line 38 of Rhode Island Red breed on MSTN and TLR4 loci.

Materials and methods. Investigations were conducted in laboratory of disease prevention and molecular diagnostics of State Poultry Research Station of NAAS. It was chosen on 50 chicken from line $\mathrm{G} 2$ and line 38 by the method of random selection. The biological material from chicken was taken by the method "a blood drop on paper". DNA was extracted by "ДНКсорб B” kit (“АмплиСенс", RF).

Individuals were genotyping by PCR-RFLP method. PCR was set by DreamTaq PCR Master Mix kit ("Thermo Scientific", USA) by such protocol: 1 cycle $-94^{\circ} \mathrm{C} / 5 \mathrm{~min} ; 35$ cycles $-94^{\circ} \mathrm{C} / 30 \mathrm{~s}, 62^{\circ} \mathrm{C} / 30 \mathrm{~s}, 72^{\circ} \mathrm{C} / 30 \mathrm{~s} ; 1$ cycle $-72^{\circ} \mathrm{C} / 5 \mathrm{~min}$. MSTN fragment (298 bp) was amplified using primer pair 5'aaccaatcgtcggtttgac-3', 5'-cgttctctgtgggctgacta-3'; TLR4 (257 bp) - primer pair 5'-cctggacttggacctcag-3', 5'-ggactgaaagctgcacatc-3' (final concentration $-0,2 \mu \mathrm{M})$. Then, it was performed restriction using Hpall enzyme for MSTN and Sau96I enzyme for TLR4 by manufacture's protocols ("Thermo Scientific", USA). Restriction fragments were separated in $1,5 \%$ agarose gel, lengths of fragments were determined by molecular mass marker M-50. The visualization of DNA- fragments was performed using ethidium bromide under UV-light.

To analyze genetic structure we calculated genotype and allele frequencies and estimated accordance of genotype frequencies distribution to Hardy-Weinberg equilibrium using $\chi^{2}$ by common methods [2].

Results. Genotypes of individuals were determined by specific restriction patterns of each amplified fragment. MSTN gene of Hpallpolymorphism has two alleles - A (restriction sites for Hpall is absent within amplified fragment) and $G$ (single restriction site). On electropherogram AA genotype is corresponded to 
single fragment (298 bp), GG - two fragments (259 and $39 \mathrm{bp}$ ), AG - three fragments (298, 259 and $39 \mathrm{bp})$. Amplified fragment of TLR4 gene have one polymorphic and two monomorphic restriction sites for Sau96I, that determines the existing of alleles $A$ (without polymorphic restriction site) and $B$ (with polymorphic restriction site). On electropherogram AA genotype was determined by fragments of length of 128, 118, $10 \mathrm{bp}$, BB genotype - 119, 89, 39, 10 bp, AB -

128, 119, 89, 39, $10 \mathrm{bp}$.

On MSTN locus genotypes frequencies in line $\mathrm{G} 2$ of White Plymouth Rock breed were: $A A-0,20$; $A G-0,27$; $G G-0,53$, and frequencies of $A$ and $G$ alleles were 0,33 and 0,67 respectively. In line 38 of Rhode Island Red breed were revealed only individuals of GG genotype, that is evidence of absence of polymorphism on this locus. TLR4 locus was found as polymorphic in both lines. In line $G 2$ genotypes frequencies were: AA 0,$06 ; A B-0,48 ; B B-0,46$. In line

38 genotypes values were: $A A-0,44 ; A B-0,44$; $B B-0,12$ respectively. Frequency of allele $A$ in line $G 2$ was 0,30 ; in line $38-0,66$; allele $B-0,70$ та 0,34 respectively; that is population of White Plymouth Rock chicken was characterized by prevalence of allele $B$ frequency, and population of Rhode Island Red chicken, on the contrary, of allele A.

It was shown through $\chi^{2}$ method that it takes place the deviation from Hardy- Weinberg equilibrium on MSTN gene in population of line G2 of White Plymouth Rock breed. On TLR4 gene both population is in the condition of genetic equilibrium. Data about factual and theoretical ratio of number of individuals with different genotypes is represented is table.

Results of investigation suggest significant differences in genetic structure between studied populations on both investigated loci, despite on fact that both lines belong to combined (or dual-purpose) type of productivity. Received data on genetic structure suggest the advisability of further work with both studied genes in line G2 and with TLR4 gene in line 38 in a cut of marker-assisted selection. 
Genetic structure of investigated lines of chicken of MSTN and TLR4 loci (Vivarium of SPRS of NAAS, 2014)

\begin{tabular}{|c|c|c|c|c|c|c|c|c|c|}
\hline \multirow[t]{2}{*}{ Locus } & \multirow[t]{2}{*}{ Genotype } & \multicolumn{4}{|c|}{$\begin{array}{l}\text { Line } \\
\text { G2 }\end{array}$} & \multicolumn{4}{|c|}{$\begin{array}{c}\text { Line } \\
38\end{array}$} \\
\hline & & $\mathrm{O}$ & $E$ & $\begin{array}{c}(\mathrm{O}- \\
\mathrm{E})^{2} / \mathrm{E}\end{array}$ & $\chi^{2}$ & 0 & $E$ & $\begin{array}{c}(\mathrm{O}- \\
\mathrm{E})^{2} / \mathrm{E}\end{array}$ & $\chi^{2}$ \\
\hline \multirow[t]{3}{*}{ MSTN } & AA & 10 & 5,5 & 3,727 & \multirow{3}{*}{8,320} & 0 & - & - & \multirow{3}{*}{ - } \\
\hline & $A G$ & 13 & $\begin{array}{c}22, \\
0\end{array}$ & 3,682 & & 0 & - & - & \\
\hline & GG & 27 & $\begin{array}{c}22, \\
5\end{array}$ & 0,911 & & 50 & - & - & \\
\hline \multirow[t]{3}{*}{ TLR4 } & AA & 3 & 4,5 & 0,500 & \multirow{3}{*}{1,021} & 22 & $\begin{array}{c}21, \\
8\end{array}$ & 0,002 & \multirow{3}{*}{0,016} \\
\hline & $A B$ & 24 & $\begin{array}{c}21, \\
0\end{array}$ & 0,429 & & 22 & $\begin{array}{c}22 \\
4\end{array}$ & 0,007 & \\
\hline & BB & 23 & $\begin{array}{c}24, \\
5\end{array}$ & 0,092 & & 6 & 5,8 & 0,007 & \\
\hline
\end{tabular}

Note. $\mathrm{O}$ - factual and $\mathrm{E}-$ theoretically expected number of individual with marked genotypes.

\section{Conclusions.}

It was found that TLR4 gene is polymorphic in both lines, whereas MSTN - only in line G2. On TLR4 gene investigated population is in the condition of genetic equilibrium, whereas on MSTN gene in line G2 is observed the deviation from Hardy-Weinberg equilibrium. Studied populations have the significant differences on genetic structure on both loci.

\section{Bibliography}

1. Kulibaba R.A. Polimorfizm genov gormona rosta, receptora gormona rosta, prolaktina i receptora prolaktina v svjazi s jaichnoj produktivnost'ju u kur porody poltavskaja glinistaja / R.A. Kulibaba // Sel'skohozjajstvennaja biologija. - 2015. - T.50, №2. - S. 198-207.

2. Merkur'eva E.K. Geneticheskie osnovy selekcii v skotovodstve / E.K. Merkur'eva - M.: «Kolos», 1977. - 240 s.

3. Hlestkina E.K. Molekuljarnye markery $\vee$ geneticheskih issledovanijah i v selekcii / E.K. Hlestkina // Vavilovskij zhurnal genetiki i selekcii. - 2013. - 
№4/2.- S. 1044-1054.

4. Associations of myostatin gene polymorphisms with performance and mortality traits in broiler chickens / X. Ye, S.R. Brown, K. Nones [et al.] // Genet. Sel. Evol.

- 2007. - Vol. 39. - P. 73-89.

5. Fulton J.E. Molecular genetics in a modern poultry breeding organization / J.E. Fulton // World's Poultry Science Journal. - 2008. - Vol. 64. - P. 171-176.

6. Genetic differ in TLR4 gene polymorphisms and expression involved in Salmonella natural and artificial infection respectively in Chinese native chicken breeds / H.F. Li, Y. Hu, H. Hu [et al.] // Mol Biol Rep. - 2013. - Vol. 40. - P. 5005-5012.

7. Malek M. Analysis of chicken TLR4, CD28, MIF, MD-2, and LITAF genes in a Salmonella enteritidis resource population / M. Malek, J.R. Hasenstein, S.J. Lamont // Poultry Science. - 2004. - Vol. 83. - P. 544-549.

8. Polymorphisms of the myostatin gene and its relationship with reproduction traits in the Bian chicken / G. Zhang, L. Zhang, Y. Wei [et al.] // Animal Biotechnology. - 2012. - Vol. 23. - P. 184-193.

9. Williams J.L. The use of marker-assisted selection in animal breeding and biotechnology / J.L. Williams // Rev. sci. tech. Off. int. Epiz. - 2005. - Vol. 24,

№1. - P. 379-391.

10. Zhu Z. SNPs of myostatin gene and its genetic effects on carcass traits in chicken / Z. Zhu, D.-J. Wu, N.Y. Xu // Hereditas (Beijing). - 2007. - Vol. 29, №5.

- P. 593-598. 